\title{
Dynamic of Filamentous Cyanobacteria in the Dam Ain Zada (North of Algeria)
}

\author{
Charifi Samia ${ }^{*}$, Merad Tarek', Guellati Fatma Zohra', \\ Touati Hassen', Bensouilah Mourad' \\ 1 Laboratory of Ecobiology of Marine and Coastal Environments, Department of Marine Sciences, Faculty of \\ Sciences, Badji Mokhtar-University, BP 12, 23000 Annaba, Algeria \\ * Corresponding author's e-mail: Samia1991270@yahoo.fr
}

\begin{abstract}
At present, harmful cyanobacterial efflorescence in Algerian water bodies used for drinking water are dominant throughout the year and their management requires a better knowledge of the cyanobacteria dynamics and the environmental parameters related to their dominance. The Ain Zada reservoir is a home of 5 genera. The occurrence frequency estimation of the identified genera shows the constancy of Planktothrix, the regularity of Aphanizomenon, Pseudanabaena and Cylindrospermopsis and the rarity of Oscillatoria. The dominant genus Planktothrix is represented exclusively by Planktothrix agardhii; this species showed the highest proportion rates in winter $(95.61 \%)$, spring $(94.80 \%)$ and autumn $(80.29 \%)$ and the lowest in summer $(29.16 \%)$. Planktothrix agardii abundances show positive relation with suspended solids and chlorophyll a and negative relation with the depth of Secchi disc. The blooms of the potential toxinogenic Planktothrix agardhii and Cylindrospermopsis are related negatively. The results from cyanotoxins and pigments characterization showed a strong positive relation of Planktothrix agardhii abundance with microcystins (MCs) and phycocyanin (PC) concentrations. Indeed, in Ain Zada dam, we found that MCs contents have positive relation with water temperature and $\mathrm{pH}$ and a negative relation with $\mathrm{NO}_{3}$. Our results show that - except for the months of March, October and November - the monthly abundances of cyanobacterial population recorded in Ain Zada dam exceeded the alert level 2. The filamentous species found in this dam are of great concern, as they are able to synthesize toxins harmful to aquatic and terrestrial organisms. Further research is needed to confirm the presence of other cyanotoxins (e.g. cylindrospermopsin) in Ain Zada dam.
\end{abstract}

Keywords: cyanobacteria; environmental parameters; Planktothrix agardhii; Ain Zada reservoir; Algeria.

\section{INTRODUCTION}

Cyanobacteria are a diverse well-adapted group of organisms; they can be found in a great variety of environments [Whitton et al., 2012]. Their strong biomasses are associated with anthropogenic eutrophication (urban and domestic waste, agricultural practices and erosion of fertile soils [Hamilton et al. 2016]. According to many authors, climate change could contribute to increasing their frequency and persistence [Paerl and Paul 2012; Carey et al. 2012; Thomas \& Litchman, 2016].

According to Paerl \& Fulton [2006], the growth and dominance of the bloom-forming cyanobacteria are controlled by abiotic and biotic factors; the factors that promote a species with specific morphology, physiology and ecology will not necessarily promote another in the same way. The ecostrategies applied by cyanobacteria allow them to become dominant.

Reynolds [1996], reported that water trophy contributes to the qualitative and quantitative composition of cyanobacterial population; filamentous forms increased and become dominant in the eutrophic or hypertrophic lakes, but their concentration decreased in the mesotrophic and oligotrophic lakes. The distribution of the dominant cyanobacteria could be linked to the specificity of the water body. 
The cyanobacterial blooms in drinking water sources and at recreational sites pose a serious threat for humans and livestock [Affsa/Afsset, 2006]. Some species of cyanobacteria produce secondary metabolites called cyanotoxins known to provide different effects; microcystins are hepatotoxic, anatoxins and saxitoxins are neurotoxic and cylindrospermopsin is cytotoxic or dermatotoxic. According to Chorus, [2001], 25 to $75 \%$ of cyanobacteria blooms are toxic. The previous studies showed that temperature, nutrients and $\mathrm{pH}$ contribute indirectly to cellular MC production and cyanobacteria growth rates [Orr \& Jones, 1998], which can account for 3 to 4 fold variation in total MC concentrations [Kurmayer et al., 2002, 2003]. Many studies reported that a climate change and increasing eutrophication would increase the toxic bloom frequency [Dokulil \& Teubner, 2011; Kosten et al., 2011; O’Neil et al., 2012; Paerl \& Paul, 2012; Slim et al., 2013].

In Algeria, water is threatened in its quality and its quantity as well as the predicted increasing needs of the population (compared to water shortages) due to the climate changes [Remini et al., 2010]. In Algerian lakes and reservoirs, several studies reported the presence of various potentially cyanotoxin-producing species.

In Oubeira lake, Bouaïcha \& Nasri, [2004] noted the co-occurence of Microcystis spp and Cylindrospermopsis raciborskii (density estimated to be $4310^{5}$ trichomes/L). In this water body, Boussadia et al. [2015] reported that cyanobacterial diversity was dominated mainly by Aphanizomenon, Oscillatoria, Cylindrospermopsis, and Microcystis. During a bloom of Microcystis Nasri et al. [2007], noted that the concentrations of Microcystins found in the liver and in the viscera were 1192.8 and $37.19 \mathrm{mg}$ MCYST-LR equivalent/g dw, respectively; this finding supports the possibility that cyanobacterial microcystins is implied in the death of the turtles. Lately, Amrani et al. (2014) noted the presence of MC in lake water of Oubeira at the concentrations ranging from 0.028 to $13.4 \mathrm{~g}$ equivalent MC-LR/l; they also reported the accumulation of MC-LR in intestine, hepatopancreas and muscle of common carp (Cyprinus carpio) and European eel (Anguilla anguilla). The presence of Microcystis spp bloom is reported in another natural lake 'lac des oiseaux' of the Northeast of Algeria by Bouhadada et al. (2016); according to these authors, the microcystins analyzed was composed of 21 putative congeners but MC-RR was the major.
In Cheffia dam, Nasri et al. [2007] noted a bloom of Microcystis sp and found in raw water, MCYST-LR equivalent concentrations ranged from 28.8 to $50.8 \mathrm{ng} / \mathrm{L}$. In Mexa reservoir, Saoudi et al. [2015] reported the constancy of Microcystis and the regularity of Oscillatoria; However, Microcystis predominates with an average density higher than 500000 cells $/ \mathrm{ml}$.

In Ain Zada dam, Saoudi et al. [2017] noted during the Planktothrix agardhii bloom that the concentrations of Microcystins ranged from 19.6 $\mu \mathrm{g} / \mathrm{L}$ MC-LR equivalent in raw water to $6.3 \mu \mathrm{g} / \mathrm{L}$ in drinking water. In the Hammam Debagh reservoir, Guellati et al. [2017] reported that the cyanobacterial community is highly dominated by Microcystis; furthermore, they noted that Planktothrix rubescens and Microcystis sp. coexisted but proliferated alternately.

In Zeralda dam Bidi-Akli et al., [2014] noted a massive mortality of fish after a succession of cyanobacteria blooms; In this water body, according to the year, blooms are represented by Planktothrix agardhii, Microcystis wesenbergi and Chamaesiphon polymorphus (Bidi-Akli et al. 2017). In Zit Emba reservoir, Touati et al. [2019], found that Microcystis represent an average proportion of $43 \%$ to global cyanobacteria population; this species was followed by Woronichinia 21\% and Planktothrix 16\%.

The current study was conducted in a hypereutrophic freshwater body subjected to Planktothrix agardhii blooms. Thus, this study aims at i) characterizing the principal environmental factors interacting with the Planktothrix agardhii dynamic in the Ain Zada reservoir, ii) determining the production of microcystins in the Ain Zada reservoir.

\section{MATERIALS AND METHODS}

\section{Study area}

The Ain Zada reservoir is a freshwater body located at $36^{\circ} 10 ’ 27.73^{\prime \prime} \mathrm{N} 5^{\circ} 08^{\prime} 58.00^{\prime \prime} \mathrm{E}$ with an average altitude of $800 \mathrm{~m}$, covering an area of $2080 \mathrm{~km}^{2}$ with a mean depth of $26 \mathrm{~m}$ and total capacity of $12110^{6} \mathrm{~m}^{3}$ [ANB BBA, 2013]. This reservoir (Fig. 1) is fed by three wadis (Boussellem, Taghrout and Kharoua); It is located in region characterized by a semi-arid climate (i.e. harsh winter and dry hot summer) where rainfall varies from 300 to $600 \mathrm{~mm}$ and air temperature ranges between $0^{\circ}$ and $38^{\circ} \mathrm{C}$; prevailing winds are northwest; sirocco is more recurrent in summer. 
This reservoir provides drinking water for cities of Sétif and Bordj Bou Arreridj. It is also used for irrigation and as an extensive aquaculture of the royal carp (Cyprinus carpio).

\section{Sample collection, field measurements and chemical analysis}

From December 2014 to November 2015, sampling was conducted monthly at sub central part of the reservoir (Fig. 1); the water samples were collected from depth of $0.5 \mathrm{~m}$ below water surface.

Cyanobacteria sampling was performed using a phytoplankton net (with $20 \mu \mathrm{m}$ of mesh size) for cyanobacteria identification and $1 \mathrm{~L}$ plastic bottle for cyanobacteria counting and chemical analysis. The in situ measurements of the water temperature (TW), dissolved oxygen (DO), $\mathrm{pH}$, and conductivity (Con) were performed using a 3420 IDS multiparameter probe (WTW, Germany). Transparency was taken with Secchi disc.

The nutrient analyses including Nitrates $\left(\mathrm{NO}_{3}\right)$, nitrites $\left(\mathrm{NO}_{2}\right)$, ammonium $\left(\mathrm{NH}_{4}\right)$ and orthophosphate $\left(\mathrm{PO}_{4}\right)$ were performed in the laboratory from the water samples stored at low temperatures for the application of spectrophotometric methods [Aminot \& Chaussepied, 1983; ISO/TC, 1994].

In order to measure the concentration of Suspended Solids matter (SS), a heat-treated $\left(450^{\circ} \mathrm{C}\right.$, $30 \mathrm{~min}$ ) glass fiber filters of $0.45 \mu \mathrm{m}$ nominal porosity (47 mm diameter, Whatman GF/CTMTM, Germany) were pre-weighed and then used for the filtration of the surface water samples. After filtration, the filters were dried at $70^{\circ} \mathrm{C}$ for $48 \mathrm{~h}$. The SS concentration was determined from the difference between the weight of the filter before and after filtration [Aminot \& Chaussepied 1983].

Cyanobacteria identification was carried out on the basis of microscopic observation of the morphological characters according to the identification keys used by Castenholz, [2001]; Komárek \& Anagnostidis, [2005]; Leitão \& Couté, [2005]. For the cyanobacteria quantification, we used $100 \mathrm{ml}$ of filtrate preserved in formaldehyde (37\%) and Nageotte counting chamber as described in Brient et al., [2001].

For the Chlorophyll a determination, water samples were filtered through $0.45 \mu \mathrm{m}$ membrane filters (47 mm diameter, Whatman GF/CTMTM, Germany). Then, pigments were extracted in $90 \%$ acetone and finally the Chlorophyll a contents were measured by a UV-visible spectrophotometer (Shimadzu UV-1700, Germany) at the wavelengths $750 \mathrm{~nm}, 630 \mathrm{~nm}, 647 \mathrm{~nm}$, and $664 \mathrm{~nm}$ [Aminot \& Chaussepied, 1983].

The Phycocyanin content was determined with the freeze-thaw method [Bennett \& Bogorad, 1973] as described by Horváth et al., [2013] in which the samples were frozen at $-20^{\circ} \mathrm{C}$. Biomass was harvested by filtration on GF/C (Whatman) filters; pigment was extracted with $10 \mathrm{ml}$ of phosphate buffer $(\mathrm{pH} 7.0)$ and its concentration was determined using a spectrophotometer at 620 $\mathrm{nm} 650 \mathrm{~nm}$ and $750 \mathrm{~nm}$.

\section{Cyanotoxin contents analysis}

For MCs analysis water samples were filtered through microfiber glass filter of $0.45 \mu \mathrm{m}$ nominal

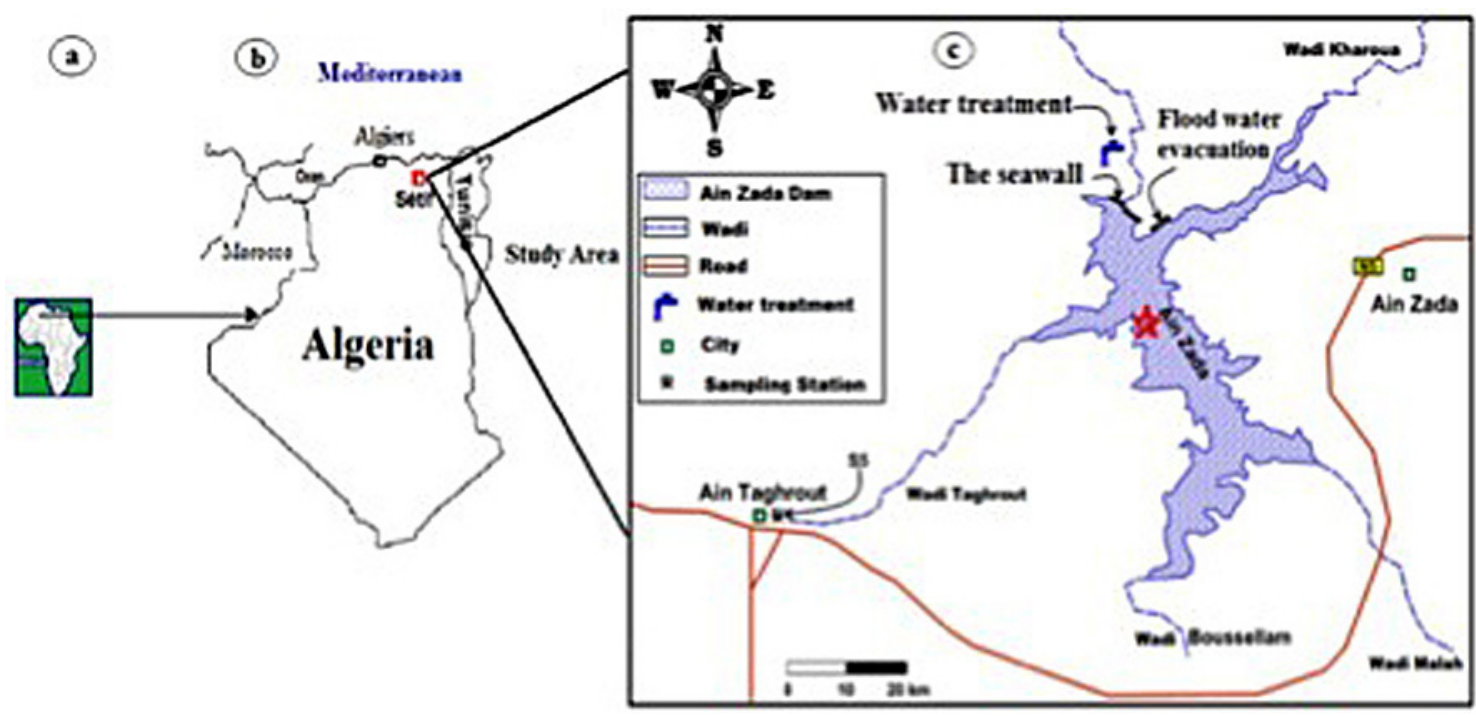

Fig. 1. Geographical position of the reservoir Ain Zada (a,b). $\star$ Star shows sampling station(c). 
porosity (47 $\mathrm{mm}$ diameter, Whatman, Germany), the filters were then kept frozen $\left(-20^{\circ} \mathrm{C}\right)$ until toxins analysis. The intracellular MCs concentrations were quantified using a commercial enzyme-linked immunosorbent assay (ELISA) kit (ABRAXIS, USA) with a mean lower detection limit of $0.15 \mathrm{ppb}$ of MCs. After extracting MCs with a methanol/water solution $(0.8 \mathrm{~V}: 0.2 \mathrm{~V})$. The essay was conducted in 96 wells plate and readings were taken at $450 \mathrm{~nm}$ wavelength using a microplate ELISA photometer (MindrayMR-96A)

\section{Statistical analysis}

For the statistical analysis of the data, we first applied the Shapiro-Wilk test then the nonparametric tests of Spearman and Kruskal-Wallis. Finally, a PCA was performed using the R facto package Miner. All statistical analyses were performed using R software (3.1.2).

\section{RESULTS}

\section{Temporal variation of the environmental variables in the dam Ain Zada}

In Ain Zada dam, the temperatures of water vary from 5.6 to $27^{\circ} \mathrm{C}$ (mean $\mathrm{T}^{\circ}=17.19^{\circ} \mathrm{C} \pm 7.20$ ); temperatures of more than $18^{\circ} \mathrm{C}$ were recorded from April to October. The waters of Ain Zada showed mean dissolved oxygen contents of 10.30 $\mathrm{mg} / \mathrm{l}( \pm 5.12)$; period extending from December to July showed more than $10 \mathrm{mg} / \mathrm{l}$ of dissolved oxygen contents ((Fig. 2a). In Ain Zada, $\mathrm{pH}$ is alkaline (mean $\mathrm{pH}$ value of $8.73( \pm 0.49)$; however, the $\mathrm{pH}$ values of more than 9 were recorded from April to July (Fig. 2b). The conductivity values in Ain Zada waters ranged from 900 to $1394 \mu \mathrm{s} / \mathrm{cm}$ (mean value of $1033 \mu \mathrm{s} / \mathrm{cm} \pm 169.11$ ); values of less than $1000 \mu \mathrm{s} / \mathrm{cm}$ were witnessed during the period between March and October. The values of suspended solids ranged between $3.2 \mathrm{mg} / \mathrm{l}$ and $185.55 \mathrm{mg} / \mathrm{l}$ (mean value $=34.91 \mathrm{mg} / \mathrm{l} \pm 50.26)$; Peaks were recorded in January $(36.8 \mathrm{mg} / \mathrm{l})$, February $(47.60 \mathrm{mg} / \mathrm{l})$, April $(185.56 \mathrm{mg} / \mathrm{l})$ and June (53.33 mg/l) (Fig. 2e). Transparency (Secchi disc) values ranged from 0.35 to $1.45 \mathrm{~m}$; transparency values of less than $0.50 \mathrm{~m}$ were recorded from February to July (Fig. 2e).

The ammonium values in Ain Zada dam water (Fig. 2d) ranged between 0.04 and $3.66 \mathrm{mg} / 1$ (mean of $0.81 \mathrm{mg} / \mathrm{l} \pm 1.03$ ); the ammonium content
$\left(\mathrm{NH}_{4}\right)$ did not exceed $0.6 \mathrm{mg} / \mathrm{l}$ except in July $(1.27 \mathrm{mg} / \mathrm{l})$, September (3.65 mg/l) October (1.57 $\mathrm{mg} / \mathrm{l})$ and November $(1.11 \mathrm{mg} / \mathrm{l}) . \mathrm{NO}_{3}$ showed values ranged from 0.56 to $4.87 \mathrm{mg} / 1$ (mean of $2.95 \mathrm{mg} / \mathrm{l} \pm 1.47$ ); the values greater than $4 \mathrm{mg} / 1$ were recorded from September to November and in February (Fig. 2c). The value of $\mathrm{NO}_{2}$ ranged between 0.01 and $0.28 \mathrm{mg} / 1$ (mean of value $=0.1$ $\mathrm{mg} / 1 \pm 0.08)$; the $\mathrm{NO}_{2}$ values remained below 0.11 $\mathrm{mg} / \mathrm{l}$ except in March $(0.18 \mathrm{mg} / \mathrm{l})$, April and May ( 0.27 and $0.24 \mathrm{mg} / 1$ respectively). The orthophosphate contents $\left(\mathrm{PO}_{4}\right)$ ranged from 0.01 to 0.30 $\mathrm{mg} / \mathrm{L}$ (mean value $=0.12 \mathrm{mg} / 1 \pm 0.07$ ); values of more than $0.11 \mathrm{mg} / \mathrm{l}$ were recorded in March and April and during the autumnal period (Fig. 2d).

The Kruskal Wallis test showed the existence of significant month-to-month differences $(p<0.05)$ for each of the variables measured.

\section{The frequency occurrence of the identified cyanobacteria in the dam of Ain Zada}

The microscopic characterization of the cyanobacteria communities of Ain Zada dam revealed the presence of five genera belonging to the order of Oscillatoriales and Nostocales. The occurrence frequency estimation of the identified genera (Table 1) showed the constancy of Planktothrix, the regularity of Aphanizomenon, Pseudanabaena and Cylindrospermopsis and the rarity of Oscillatoria. The main representatives of the cyanobacterial community were Planktothrix, Cylindrospermopsis and Aphanizomenon (Table 1).

Table I. Occurrence and proportional rates of identified cyanobacteria in Ain Zada dam

\begin{tabular}{|l|c|c|}
\hline \multicolumn{1}{|c|}{ Genera } & $\mathrm{F}(\%)$ & $\begin{array}{c}\text { Proportional } \\
\text { rates (\%) }\end{array}$ \\
\hline Planktothrix & 91.66 (Constant) & 69 \\
\hline Cylindrospermopsis & 50 (Regular) & 14.9 \\
\hline Aphanizomenon & 66.66 (Regular) & 13.65 \\
\hline Pseudanabaena & 66.66 (Regular) & 2 \\
\hline Oscillatoria & 8.33 (Rare) & 0.04 \\
\hline
\end{tabular}

\section{Temporal abundance of the identified cyanobacteria in the dam of Ain Zada}

The monthly variation of the total cyanobacteria population recorded in the reservoir of Ain Zada dam showed that the abundances exceeded the alert level 2 throughout the year except for the months of March, October and November (Fig. 3). 

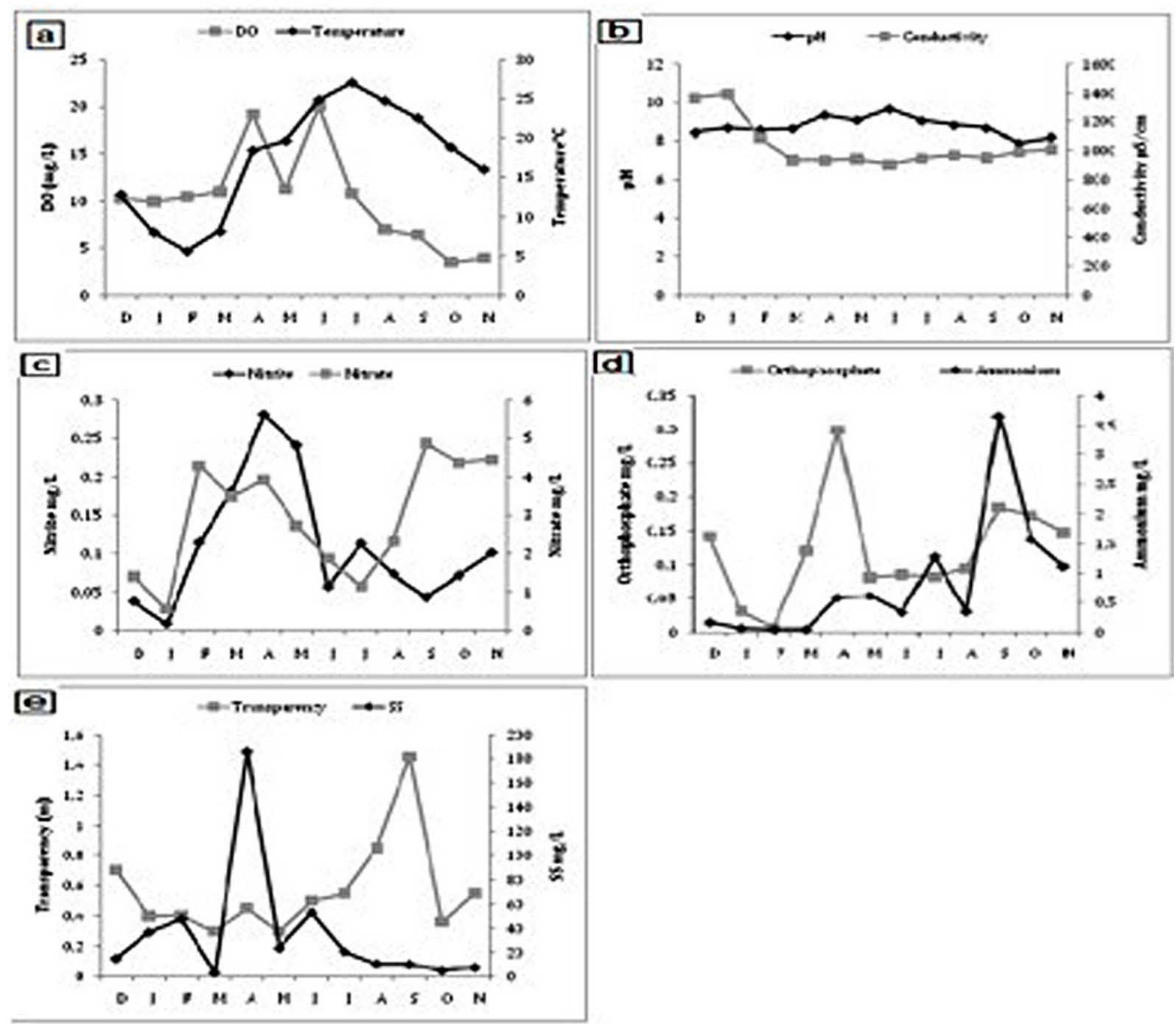

Fig. 2. Monthly variations of temperature-DO (a), conductivity-pH (b), $\mathrm{NO}_{3}$ $\mathrm{NO}_{2}(\mathrm{c}) ; \mathrm{NH}_{4}-\mathrm{PO}_{4}(\mathrm{~d})$ and SS-Trans (e) in Ain Zada dam.

In Ain Zada dam, the monthly Planktothrix abundance values ranged from undetected in September to 2444800 cells $/ \mathrm{ml}$ in June with a mean value of 674181 cells $/ \mathrm{ml}$. This genus was strongly present from April to July where abundance values exceeded one million cells/ml (Fig. 4).

Planktothrix showed a strong positive correlation with phycocyanin $(\mathrm{r}=0.86 ; \mathrm{p} \leq 0.001)$ and suspended solids $(\mathrm{r}=0.83 ; \mathrm{p}<0.01)$. This genera was correlated positively with chlorophyll $a(\mathrm{r}=0.74$; $\mathrm{p} \leq 0.01)$ and microcystin $(\mathrm{r}=0.72 ; \mathrm{p} \leq 0.01)$ and negatively with $\mathrm{NO}_{3}(\mathrm{r}=-0.67 ; \mathrm{p}<0.05)$.

The monthly abundance values of Cylindrospermopsis genus varied from 0 to 1694933 cells $/ \mathrm{ml}$ with a mean value of 144848 cells $/ \mathrm{ml}$. The highest value was recorded in September and three peaks of 9 485, 13637 and 13201 cells/ $\mathrm{ml}$ were noted in August, July and December, respectively (Fig. 4).
Aphanizomenon showed that the monthly abundance values ranged from 0 to 854400 cells/ $\mathrm{ml}$ (mean value of 132679 cells $/ \mathrm{ml}$ ). This genus showed four peaks of $28800,278400,406400$ and 854400 cells $/ \mathrm{ml}$ respectively in May, April, August and September (Fig. 4).

The monthly Pseudanabaena abundance values varied from 0 to 106667 cells/ml (in July) (mean value of 19499 cells $/ \mathrm{ml}$ ); values of more than 13000 cells $/ \mathrm{ml}$ were noted in August (13 067 cells $/ \mathrm{ml})$, September (26133 cells $/ \mathrm{ml})$, October (28267 cells $/ \mathrm{ml}$ ) and November (43840 cells $/ \mathrm{ml}$ ).

Spearman correlation test showed a strong negative correlation between Pseudanabaena and DO $(\mathrm{r}=-0.76 ; \mathrm{p}<0.01)$, and positive correlation between Pseudanabaena and $\mathrm{NH}_{4}(\mathrm{r}=0.66 ; \mathrm{p}<0.05)$ and conductivity $(\mathrm{r}=0.64 ; \mathrm{p}<0.05)$. During this study, Oscillatoria was present only in November with the abundance value of 5600 cells $/ \mathrm{ml}$. 


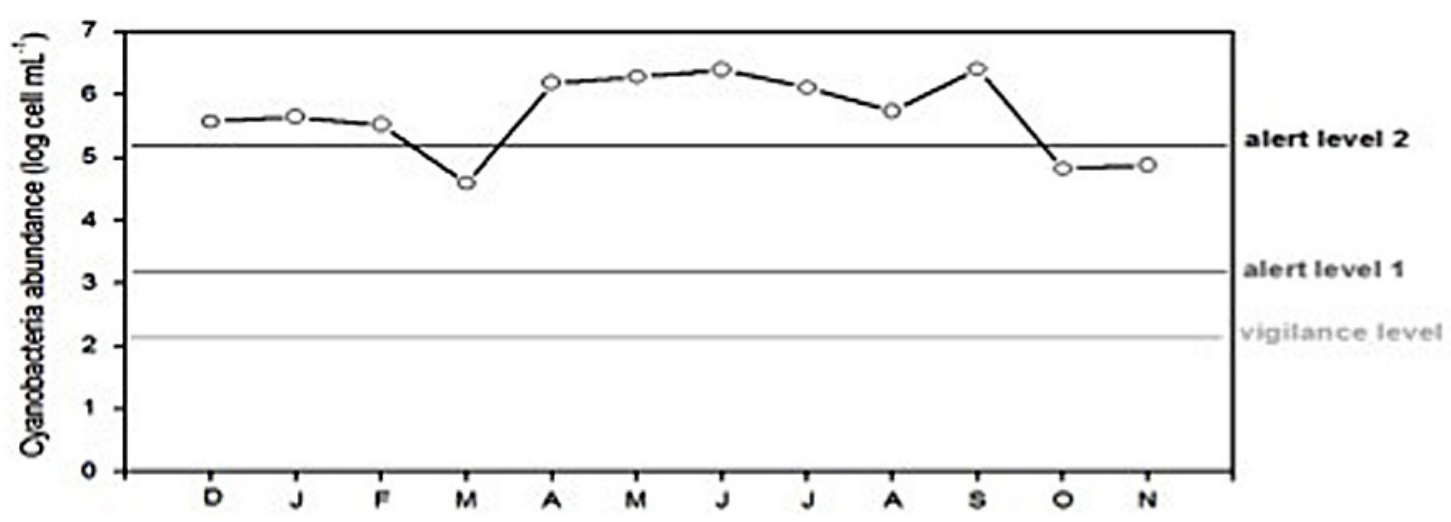

Fig. 3. Monthly variation of the total cyanobacteria population recorded in the dam Ain Zada

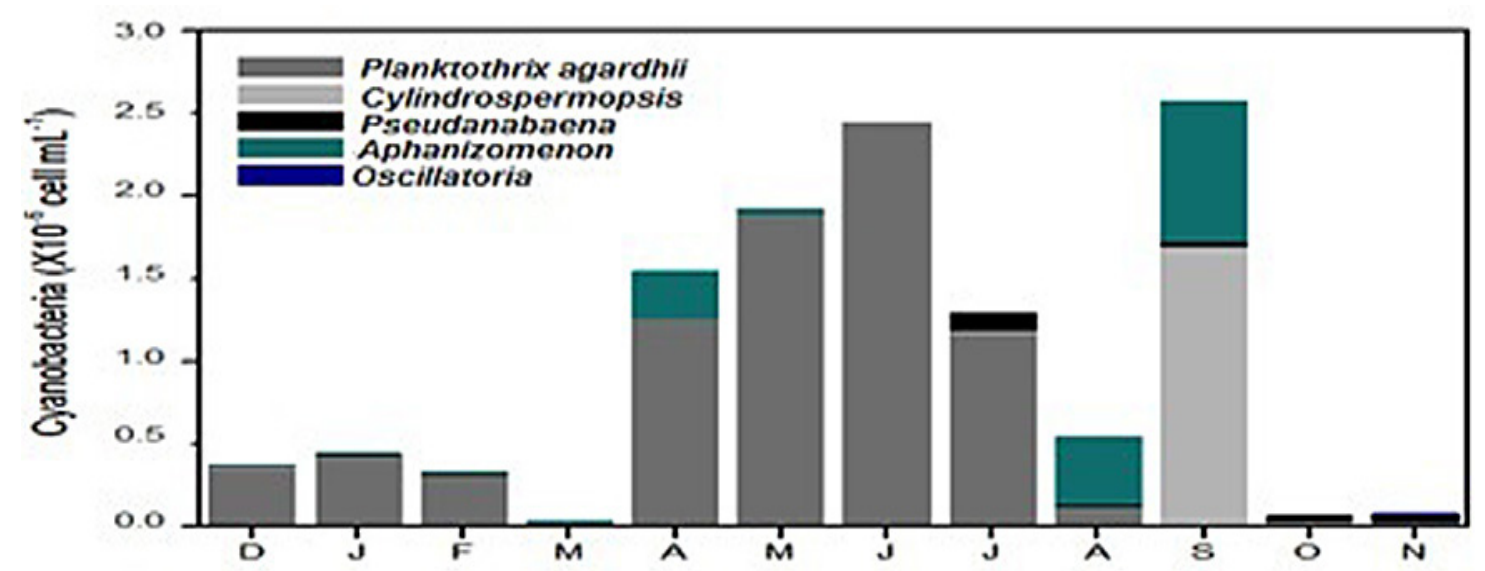

Fig. 4. Abundance of main genera of cyanobacteria in the dam Ain Zada (from December 2014 to November 2015)

\section{Temporal variation of the Chlorophyll a and phycocyanin}

The monthly chlorophyll $a$ contents ranged from 13.25 to $172.79 \mu \mathrm{g} / \mathrm{l}$. The highest values of chlorophyll $a$ contents (more than 100 $\mu \mathrm{g} / \mathrm{l})$ were recorded from April to June; values ranged from 50 to $100 \mu \mathrm{g} / 1$ were noted in January, July, August, September and December. The lowest values (less than $50 \mu \mathrm{g} / \mathrm{l}$ ) were recorded in February, March, October and November (Fig. 5). The monthly phycocyanin contents ranged from 39.97 (October) to $387.39 \mu \mathrm{g} / 1$ (June). This pigment showed highest levels in spring and summer and the lowest in winter (Fig. 5).

The non-parametric Spearman correlation showed a strong positive correlation between the chlorophyll a contents and the abundances of cyanobacteria $(r=0.75 ; \mathrm{p}<0.01)$, and a very high positive correlation between the chlorophyll $a$ contents and phycocyanin contents $(\mathrm{r}=0.9 ; \mathrm{p}<0.001)$.

\section{Temporal variation of the intracellular microcystins content}

The microcystins levels recorded monthly in the water of Ain Zada dam showed the values of more than $1 \mu \mathrm{g} / \mathrm{ml}$ from April to July and in November (Fig. 6); two peaks of 4.77 and $3.79 \mu \mathrm{g} / \mathrm{l}$ were recorded in June and July, respectively. During the rest of the year, microcystin contents did not exceed $0.5 \mu \mathrm{g} / \mathrm{l}$.

A strong positive correlation was found between MCs and Chlorophyll a $(r=0.79 ; \mathrm{p}<0.01)$, MCs and phycocyanin contents $(\mathrm{r}=0.83 ; \mathrm{p}<0.01)$, MCs and Planktothrix abundance $(\mathrm{r}=0.72 ; \mathrm{p} \leq 0.01)$. The temperature of water seemed to be positively correlated with microcystin contents ( $r=0.64 ; \mathrm{p}<0.05$ ).

\section{Relationship between environmental variables and cyanobacteria in the dam of Ain Zada}

The first two main components (Table 2-3, Fig. 7-8) of the PCA carried out on the 


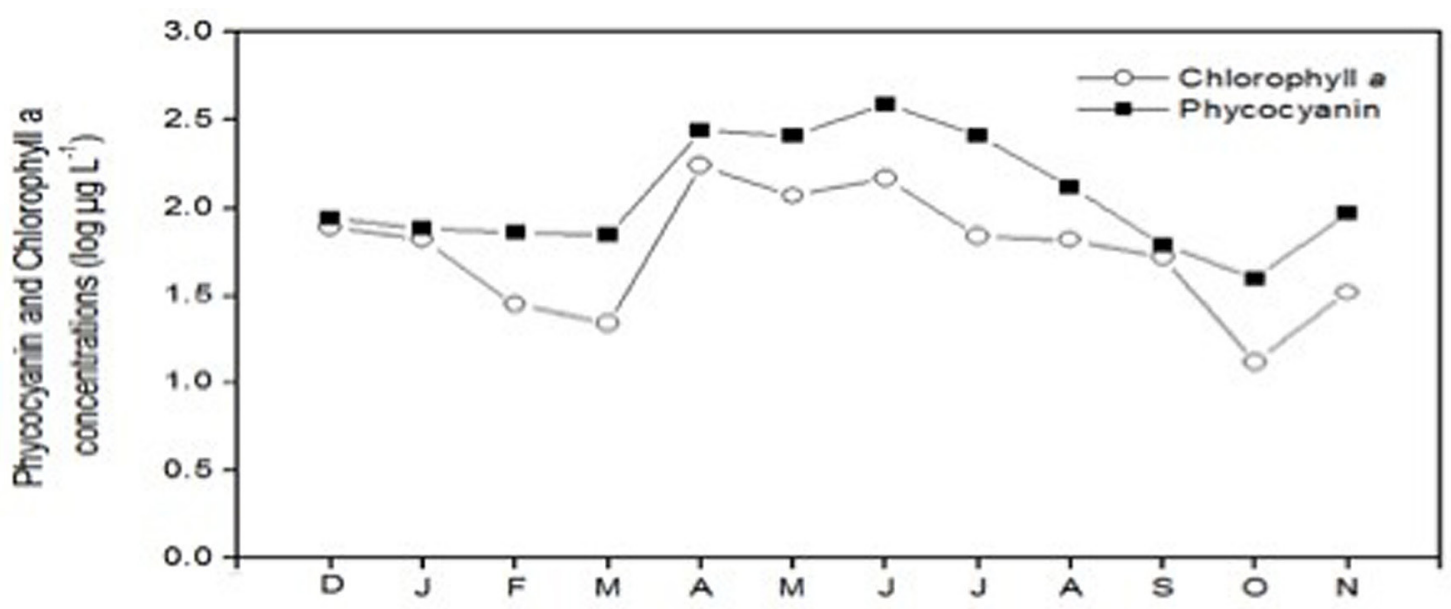

Fig. 5. Monthly variations of chlorophyll a and Phycocyanin levels in Ain Zada dam

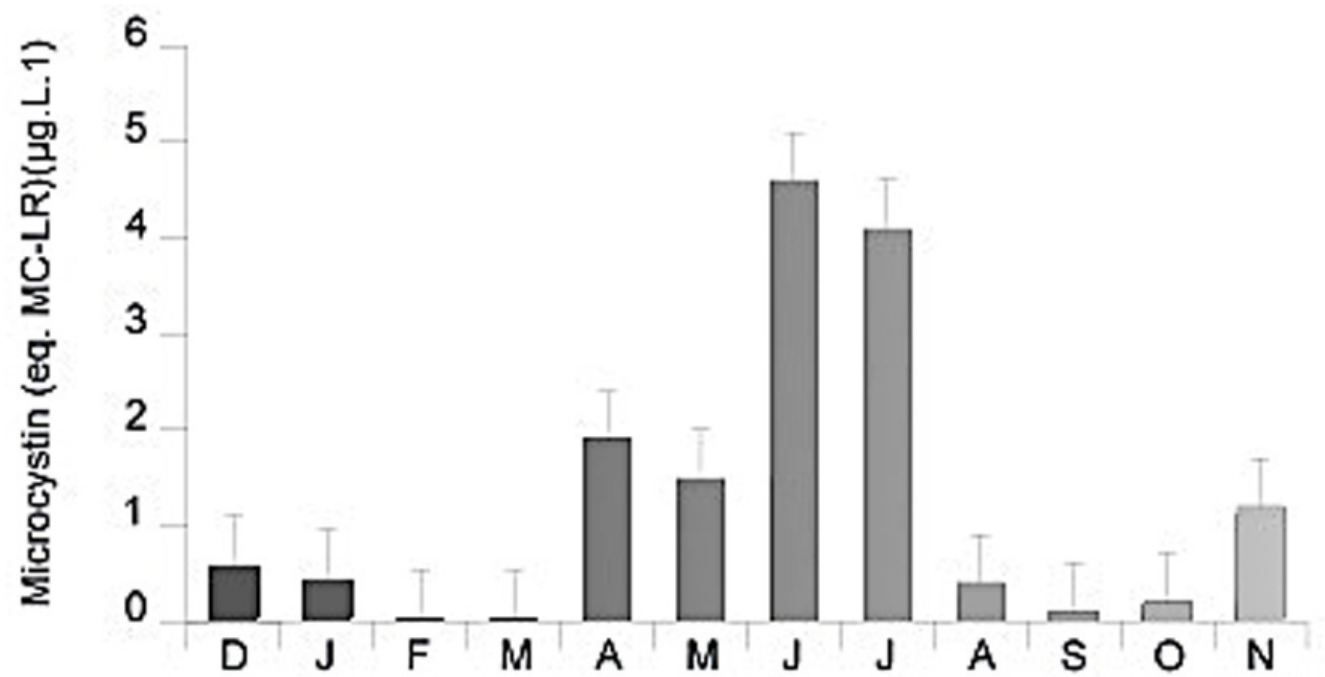

Fig. 6. Monthly variations of Microcystins contents from the samples collected in the reservoir Ain Zada

ten environmental variables resulted in almost $65.83 \%$ of the information (inter-month variability). The counts of the different genus were used as additional quantitative variables.

Axis 1 accounts for $43.33 \%$ of the total variability. This axis is correlated positively with the variable $\mathrm{Chl} \mathrm{a}(\mathrm{r}=0.92), \mathrm{pH}(\mathrm{r}=0.92), \mathrm{DO}(\mathrm{r}=$ $0.91)$, phyco $(r=0.91)$, PLkt $(r=0.83)$, MCs $(r$ $=0.72), \mathrm{SS}(\mathrm{r}=0.74), \mathrm{NO}^{2}(\mathrm{r}=0.59)$; it is negatively correlated with Trans $(r=-0.66)$. On the positive pole of axis 1 , are projected months of April, May, June and July where Planktothrix bloom occurred.

Axis 2 accounts for $22.49 \%$ of the total variation; it is constructed essentially by the variable $\mathrm{NH}_{4}(\mathrm{r}=0.76), \mathrm{NO}_{3}(\mathrm{r}=0.75), \mathrm{PO}_{4}(\mathrm{r}=0.70)$, and $\mathrm{TW}(\mathrm{r}=0.50)$; on the negative pole of axis 2 , water conductivity was projected which contributes to its construction $(\mathrm{r}=-0.71)$.

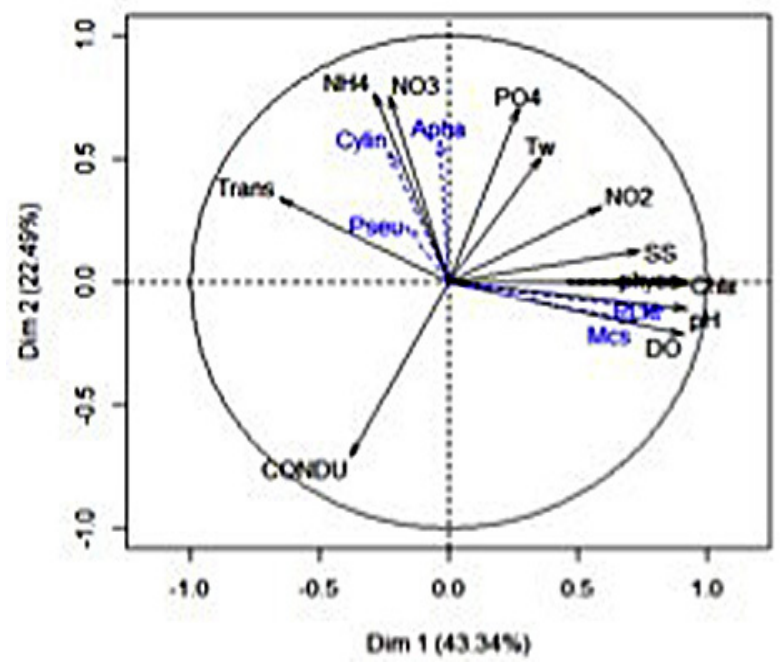

Fig. 7. Circle of correlations of environmental variables with the first two axes of the standardized PCA 


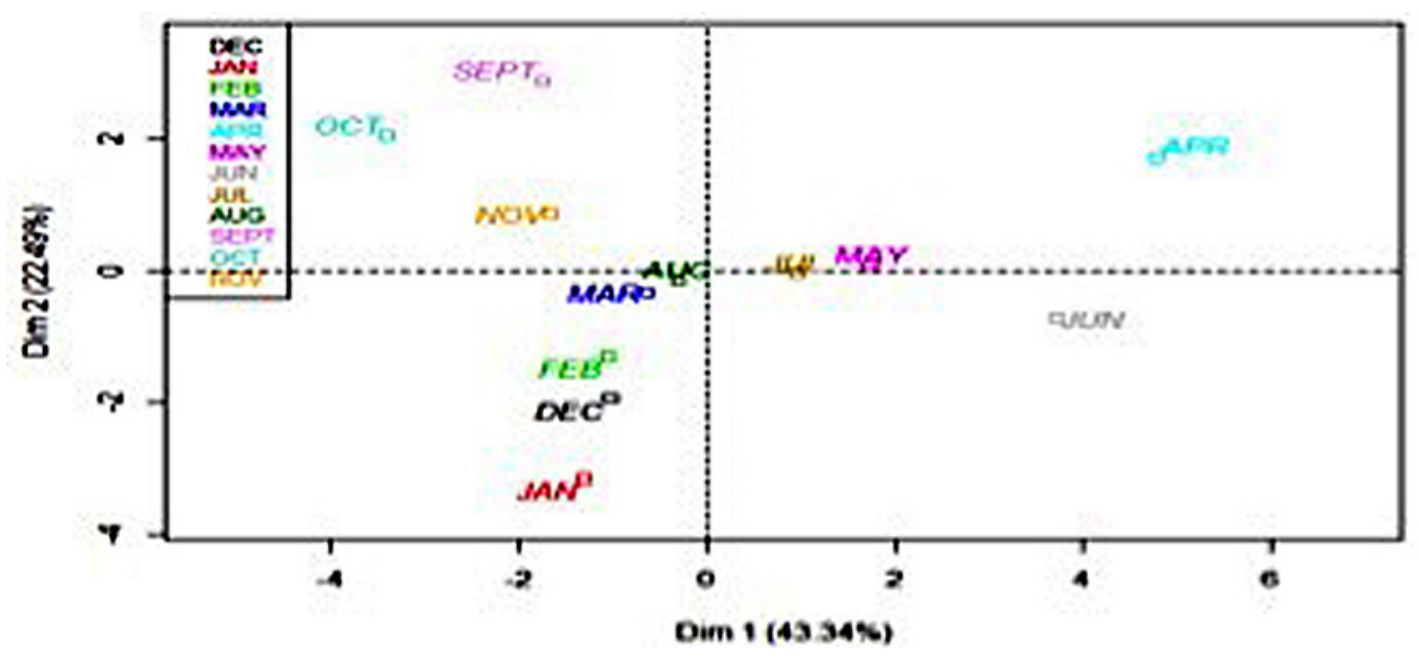

Fig. 8. Projected months on the first two main axes of the standardized PCA
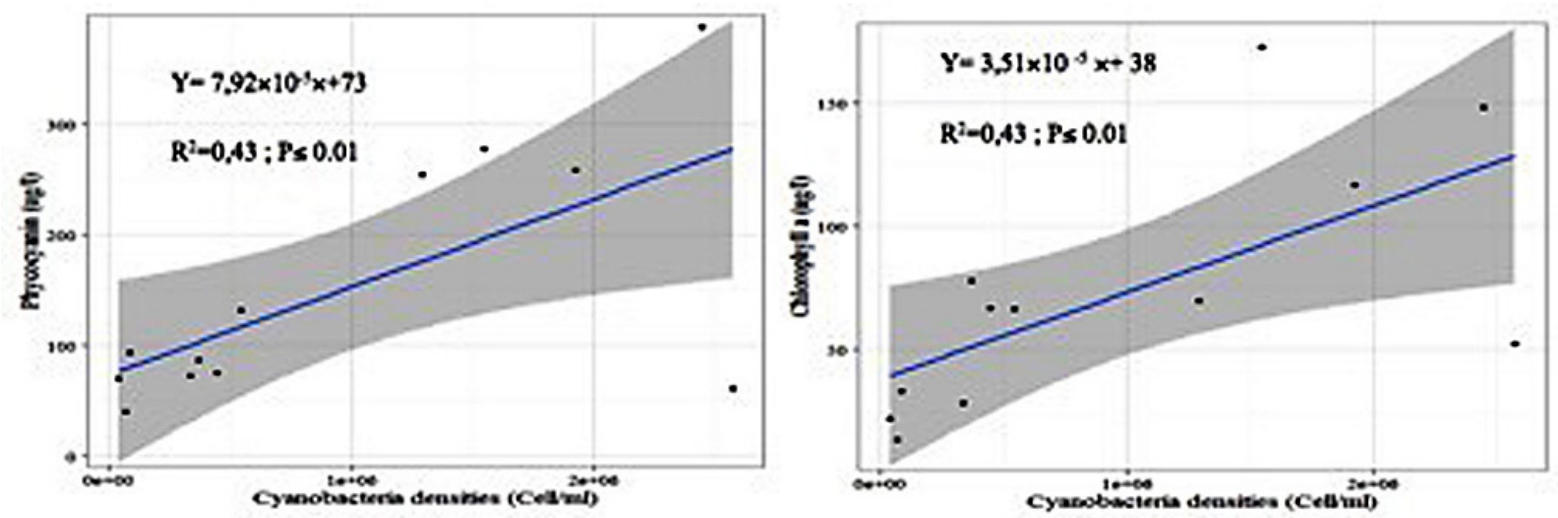

Fig. 9. Relationship between abundance of Cyanobacteria and its related pigments: phycocyanin (left) and chlorophyll $a$ (right)

Table 2. Physicochemical variable of water of Ain Zada dam

\begin{tabular}{|c|c|c|c|c|c|c|}
\hline & mean & $\mathrm{SD}$ & $\mathrm{CV}$ & Min & Median & Max \\
\hline $\mathrm{CON}(\mu \mathrm{S} / \mathrm{cm})$ & 1033.25 & 169.11 & 0.16 & 900 & 955.50 & 1394 \\
\hline $\mathrm{DO}(\mathrm{mg} / \mathrm{L})$ & 10.30 & 5.12 & 0.49 & 3.49 & 10.34 & 20.00 \\
\hline $\mathrm{NH}_{4}(\mathrm{mg} / \mathrm{L})$ & 0.81 & 1.03 & 1.26 & 0.04 & 0.46 & 3.66 \\
\hline $\mathrm{NO}_{2}(\mathrm{mg} / \mathrm{L})$ & 0.10 & 0.08 & 0.76 & 0.01 & 0.08 & 0.28 \\
\hline $\mathrm{NO}_{3}(\mathrm{mg} / \mathrm{L})$ & 2.95 & 1.47 & 0.49 & 0.56 & 3.10 & 4.87 \\
\hline $\mathrm{pH}$ & 8.73 & 0.49 & 0.05 & 7.87 & 8.65 & 9.66 \\
\hline $\mathrm{PO}_{4}(\mathrm{mg} / \mathrm{L})$ & 0.12 & 0.076 & 0.64 & 0.01 & 0.10 & 0.30 \\
\hline $\mathrm{SS}(\mathrm{mg} / \mathrm{L})$ & 34.91 & 50.26 & 1.43 & 3.20 & 17.93 & 185.56 \\
\hline $\mathrm{TW}\left({ }^{\circ} \mathrm{C}\right)$ & 17.19 & 7.20 & 0.41 & 5.60 & 18.60 & 27.00 \\
\hline Trans $(\mathrm{m})$ & 0.56 & 0.32 & 0.56 & 0.30 & 0.47 & 1.45 \\
\hline
\end{tabular}

CON: Conductivity, $(\mu \mathrm{s} / \mathrm{cm})$; DO: dissolved oxygen, $(\mathrm{mg} / \mathrm{L}) ; \mathrm{NH}_{4}$ : ammonium, $(\mathrm{mg} / \mathrm{L}) ; \mathrm{NO}_{2}$ : Nitrite, $(\mathrm{mg} / \mathrm{L})$; $\mathrm{NO}_{3}$ : Nitrate, (mg/L); pH: Potential hydrogen; $\mathrm{PO}_{4}(\mathrm{mg} / \mathrm{L})$ : Orthophosphate; SS: suspended solids, (mg/L); TW: water temperature, $\left({ }^{\circ} \mathrm{C}\right)$; Trans: transparency, $(\mathrm{m})$. 
Table 3. Spearman correlation coefficients

\begin{tabular}{|c|c|c|c|c|c|c|c|c|c|c|c|c|c|c|c|c|c|}
\hline & Apha & Chla & CON & Cylin & DO & Mcs & $\mathrm{NH}_{4}$ & $\mathrm{NO}_{2}$ & $\mathrm{NO}_{3}$ & $\mathrm{pH}$ & Phyco & PLkt & $\mathrm{PO}_{4}$ & Pseu & SS & Trans & Tw \\
\hline Apha & 1.00 & & & & & & & & & & & & & & & & \\
\hline Chla & 0.21 & 1.00 & & & & & & & & & & & & & & & \\
\hline CON & -0.08 & $-0.66^{*}$ & 1.00 & & & & & & & & & & & & & & \\
\hline Cylin & 0.40 & -0.02 & 0.31 & 1.00 & & & & & & & & & & & & & \\
\hline DO & 0.06 & $0.73^{* *}$ & $-0.84^{* *}$ & -0.30 & 1.00 & & & & & & & & & & & & \\
\hline Mcs & -0.34 & $0.79^{* *}$ & -0.60 & -0.25 & 0.55 & 1.00 & & & & & & & & & & & \\
\hline $\mathrm{NH} 4$ & -0.00 & -0.03 & 0.20 & 0.30 & -0.54 & 0.11 & 1.00 & & & & & & & & & & \\
\hline $\mathrm{NO} 2$ & 0.05 & 0.21 & -0.23 & -0.40 & 0.45 & 0.11 & -0.34 & 1.00 & & & & & & & & & \\
\hline NO3 & 0.20 & -0.51 & 0.52 & -0.02 & $-0.63^{*}$ & $-0.63^{*}$ & 0.37 & -0.20 & 1.00 & & & & & & & & \\
\hline $\mathrm{pH}$ & 0.22 & $0.93^{* * *}$ & $-0.81^{* *}$ & -0.02 & $0.86^{\star \star \star}$ & $0.72^{* \star}$ & -0.19 & 0.19 & $-0.66^{*}$ & 1.00 & & & & & & & \\
\hline Phyco & -0.05 & $0.91^{* * *}$ & $-0.62^{*}$ & -0.23 & $0.80^{* *}$ & $0.83^{* *}$ & -0.30 & 0.32 & $-0.67^{*}$ & $0.87^{\star * \star}$ & 1.00 & & & & & & \\
\hline PLkt & -0.20 & $0.74^{* *}$ & -0.47 & -0.29 & $0.73^{* *}$ & $0.72^{* *}$ & -0.28 & 0.32 & $-0.67^{*}$ & $0.74^{\star *}$ & $0.86^{\star * \star}$ & 1.00 & & & & & \\
\hline PO4 & 0.23 & -0.01 & -0.18 & -0.19 & -0.22 & -0.03 & 0.43 & -0.15 & 0.56 & -0.10 & -0.24 & -0.42 & 1.00 & & & & \\
\hline Pseu & -0.33 & -0.37 & $0.64^{*}$ & 0.49 & $-0.76^{\star *}$ & -0.06 & $0.66^{*}$ & -0.39 & 0.22 & -0.53 & -0.43 & -0.42 & 0.02 & 1.00 & & & \\
\hline SS & 0.13 & $0.80^{* *}$ & -0.36 & -0.00 & $0.68^{*}$ & 0.51 & -0.27 & 0.25 & -0.38 & $0.74^{* *}$ & $0.79^{* *}$ & $0.83^{\star \star}$ & -0.24 & -0.42 & 1.00 & & \\
\hline Trans & 0.21 & -0.48 & 0.44 & 0.53 & $-0.67^{*}$ & -0.41 & 0.58 & -0.40 & 0.18 & -0.44 & $-0.66^{*}$ & -0.46 & 0.01 & 0.52 & -0.54 & 1.00 & \\
\hline Tw & -0.03 & 0.52 & -0.36 & 0.40 & 0.17 & $0.64^{*}$ & 0.40 & -0.43 & -0.58 & 0.56 & 0.40 & 0.35 & -0.10 & 0.23 & 0.21 & 0.27 & 1.00 \\
\hline
\end{tabular}

Pseu: Pseudanabaena, (Cell/ml); SS: suspended solids, (mg/L); Trans: transparency, $(\mathrm{m}) ; \mathrm{TW}$ : water temperature, $\left({ }^{\circ} \mathrm{C}\right)$. $* \mathrm{p} \leq 0.05 ; * * \mathrm{p} \leq 0.01 ; * * * \mathrm{p} \leq 0.001$

Apha: Aphanizomenon, (Cell/ml); Chla: Chlorophyll a, $(\mu \mathrm{g} / \mathrm{L}) ; \mathrm{CON}$ : Conductivity, $(\mu \mathrm{s} / \mathrm{cm}) ;$ Cylin: Cylindrospermopsis, (Cell/ml); DO: dissolved oxygen, (mg/L); MCs: Microcystins, ( $\mu \mathrm{g} / \mathrm{L}) ; \mathrm{NH}_{4}$ : ammonium, $\left(\mathrm{mg}_{\mathrm{L}}\right)$; $\mathrm{NO}_{2}$ : Nitrite, $(\mathrm{mg} / \mathrm{L}) ; \mathrm{NO}_{3}$ : Nitrate, $(\mathrm{mg} / \mathrm{L}) ; \mathrm{pH}$ : potential hydrogen; Phyco : phycocyanin, $(\mu \mathrm{g} / \mathrm{L})$; PLkt: Planktothrix, $(\mathrm{Cell} / \mathrm{ml}) ; \mathrm{PO}_{4}$ : Orthophosphate, $(\mathrm{mg} / \mathrm{L})$.

\section{DISCUSSION}

The microscopic characterization of the cyanobacteria communities in the water of Ain Zada dam revealed the exclusive presence of filamentous cyanobacteria belonging to the orders of Oscillatoriales and Nostocales. The occurrence frequency estimation of the identified genera showed the constancy of Planktothrix, the regularity of Aphanizomenon, Pseudanabaena and Cylindrospermopsis and the rarity of Oscillatoria. The dominant genus Planktothrix was represented exclusively by $P$. agardii. Blooms of this species were observed from winter to summer with a proportion rate exceeding $80 \%$ from the whole cyanobacteria.

According to Scheffer et al. [1997] the growth of Planktothrix agardhii is favored by the conditions of greater turbid waters with a high disturbance frequency. In addition, Nixdorf et al. [2003] place these species in the phytoplankton functional group S1 [sensu Reynolds et al., 2002] of photoadapting filamentous cyanobacteria common in shallow and wind-exposed lakes with strong interactions between sediment and water and having low light levels. These findings were supported by the high positive correlation of $P$. agardhii abundances and the measures of suspended solids observed in the reservoir of Ain Zada.

According to Dokulil and Teubner [2000] and Kokocinsky et al. [2010], in temperate lakes, low temperature did not stop the growth of $P$. agardhii; Poulickova et al. [2004] noted, that P. agardhii in eutrophic lakes grow even in winter. This could explain the low positive correlation of $P$. agardhii abundances with the water temperature in the dam Ain Zada; Moreover, the cells abundances of this species were correlated positively with chlorophyll a and negatively with the depth of Secchi disk.

According to the OCDE classification scheme, the chlorophyll a and transparency values noted in Ain Zada dam showed that this water body fluctuated between the eutrophic and hypereutrophic status [Vollenweider and Kerekes, 1982].

The lower values of transparency observed in the Ain Zada dam explained the mass occurrence of Planktothrix agardii throughout the year. In Ain Zada dam, high levels of phosphorus were observed during the Planktothrix agardii bloom. However, no correlations were noted with phosphorus. In Zit Emba reservoir, Touati et al. [2019] reported the positive correlation between the PO4 -P concentrations and the Planktothrix abundance 
suggesting that the growth rate of this genus was increased by high orthophosphates concentrations. This corroborates the results reported by Bidi-Akli et al. [2017] in Zeralda dam (Algeria).

According to Kokocinski et al. [2010], Planktothrix agardhii and Cylindrospermopsis raciborskii could grow under different environmental requirements. This finding is in good concordance with the dynamics of these two cyanobacteria in Ain Zada reservoir. Indeed, a bloom of Cylindrospermopsis was observed in September and the presence of this species overlapped with the highest transparency and highest ammonium values and the absence of Planktothrix agardhii. Our results show the impact of the light on the composition of the phytoplankton community; we noted, indeed, a community was dominated by $P$. agardhii in very turbid waters, in relation to more diverse communities including the invasive Cylindrospermopsis in clearer waters. Several studies indicated that $C$. raciborskii is generally more restricted to dry periods with low rainfall [Chellappa and Costa, 2003] and high temperatures [Bouvy et al., 2006]. In the reservoirs, during dry periods, the long period of water retention provide good conditions of temperature and irradiation for the dominance of the species $C$. raciborskii [Bouvy et al., 2000].

Studies from different geographical regions, indicated a frequent co-occurrence of C. raciborskii with another invasive species, Chrysosporum ovalisporum, which is also a potential producer of cylindrospermopsin [Quesada et al., 2006 ; Yilmaz et al., 2008; Messineo et al., 2010; Orr et al., 2010]. The first report of the cyanobacterium C. raciborskii in Algerian freshwaters was in 2000 by Bouaicha and Nasri [2004]; the same authors reported its co-dominance with Microcystis in the lake Oubeira. Moreover, Boussadia et al. [2015] reported, in the same lake, the cooccurrence of Aphanizomenon (53\%), Oscillatoria (21\%), Cylindrospermopsis (11\%), Microcystis $(10 \%)$, and mixture of other genera $(5 \%)$. In the Ain Zada dam, the highest proportion of Aphanizomenon was recorded in the beginning of autumn. According to Mehnert et al., [2010] the genus Aphanizomenon showed a preference for high temperatures. In the lake Oubeira, Boussadia et al., [2015] recorded higher cyanobacteria abundances in summer and autumn, when Cuspidothrix issatschenkoi blooms occurred.

In Ain Zada dam, the results from cyanotoxins and pigments characterization showed a strong positive correlation of $P$. agardhii abundance with the concentrations of microcystins (MCs) and phycocyanin (PC); this led us to conclude that the detected $\mathrm{MC}$ and $\mathrm{PC}$ in the collected samples derived from this cyanobacterium.

Grabowska and Pawlik-Skowronska [2008] reported an increase in MCs concentrations which overlapped with a strong increase in $P$. agardhii. Moreover, in Poland Solis et al. (2012) found a correlation between MC-RR level and $P$. agardhii abundance in the eutrophic reservoirs of Tomaszne. According to Barco et al. [2004]; Kurmayer et al. [2004]; Welker et al. [2004], in "Planktothrix lakes", the demethylated MC-RR should be the principal microcystin variant.

According to Kurmayer and Christiansen [2009], temperature, nutrients and $\mathrm{pH}$ can induce changes in the cyanotoxin content in individual strain, by a factor of no more than three to four. Indeed, in the Ain Zada dam, the MCs contents are correlated positively with water temperature $(\mathrm{r}=0.64)$ and $\mathrm{pH}(\mathrm{r}=0.72)$ and negatively with $\mathrm{NO}_{3}(\mathrm{r}=-0.63)$.

Except for the months of March, October and November the monthly abundance of cyanobacterial populations recorded in Ain Zada dam exceeded the alert level 2 [Affsa/Afsset, 2006].

The strong and permanent dominance of $P$. agardhii over other toxic species impacted the water quality negatively. The filamentous species met in the Ain Zada dam were of great concern because they can synthesize toxins harmful to aquatic and terrestrial fauna [Kuiper-Goodman et al., 1999; Xie et al., 2007; Pawlik-Skowronska et al., 2012]

The species $P$. agardhii is known for synthesizing a variety of microcystin [Carmichael, 1994; Chorus, 2001; Kurmayer et al., 2004; Welker et al., 2004; Rohrlack et al., 2008; Solis et al., 2012], while $C$. raciborskii is able to produce the neurotoxin 'saxitoxin' [Lagos et al., 1999; Castro et al., 2004] and the hepatotoxin 'cylindrospermopsin' [Ohtani et al., 1992; Li et al., 2001]. According to Cirés and Ballot (2016), several members of the genus Aphanizomenon have the ability to develop blooms and to synthesize microcystins (hepatotoxins), anatoxins and saxitoxins (neurotoxins) and cylindrospermopsin (cytotoxins). Pseudanabaena species could represent a potential risk for exposed fauna, because the presence of neuro and hepatotoxins in extract and neurotoxin in growth medium of Pseudanabaena galeata has been shown (Teneva et al., [2009]). 
According to Codd [2000], the fact that toxigenic cyanobacteria are present in these drinking water production reservoirs involves regular monitoring of cyanobacterial populations and cyanotoxins in raw water. This monitoring should be undertaken, due to its potential health risk for drinking water and for bioaccumulation of cyanotoxins in the flesh of fish [Jia et al., 2014; Amrani et al., 2014]. The establishment of a wastewater treatment could help to reduce nutrients loads discharged in the watershed in order to prevent eutrophication and development of toxic cyanobacterial blooms.

\section{CONCLUSION}

Blooms of the potential toxinogenic P. agardhii and Cylindrospermopsis were related negatively. The occurrence of blooms of $P$. agardhii in the dam of Ain Zada was observed from winter to summer. In turn, the blooms of the invasive $\mathrm{Cyl}$ indrospermopsis were observed in autumn. This succession was explained by their possible different responses to environmental constraints resulting in contrasting strategies. The most important environmental variables probably leading to this succession was the water transparency and the suspended solid matter (SS). Thus, P. agardhii is favored by turbid conditions, while Cylindrospermopsis prefers less turbid waters.

\section{Acknowledgements}

We acknowledge the excellent assistance provided by the staff of the Ain Zada National Agency of Dams and Transfers (ANBT) specially principal Dahoui Kamel and greatly the General Directorate for Scientific Research and Technological Development (DGRSDT). A special thanks to my dear father Charifi Salah who helped me.

\section{REFERENCES}

1. Afssa/Afsset. 2006. Évaluation des risques liés à la présence de cyanobactéries et de leurs toxines dans les eaux destinées à l'alimentation, à la baignade et autres activités récréatives. Rapport commun sur les risques sanitaires liés à la présence de cyanobactéries dans l'eau, p. 232. [In French]

2. Aminot A., Chaussepied M. 1983. Manuel des analyses chimiques en milieu marin (No. 551.464 AMI). [In French]
3. Amrani A., Nasri H., Azzouz A., Kadi Y., Bouaïcha N. 2014. Variation in cyanobacterial hepatotoxin (microcystin) content of water samples and two species of fishes collected from a shallow lake in Algeria. Archives of Environmental Contamination and Toxicology, 66(3), 379-389.

4. ANB BBA (Agence National des Barrages Bordj Bou Arreridj). 2013. Données des caractéristiques techniques du Barrage Ain Zada. [In French]

5. Barco M., Flores C., Rivera J., Caixach J. 2004. Determination of microcystin variants and related peptides present in a water bloom of Planktothrix (Oscillatoria) rubescens in Spanish drinking water reservoir by LC/ESI-MS - Toxicon 44: 881-886.

6. Bennett A., Bogorad L. 1973. Complementary chromatic adaptation in a filamentous blue-green alga. The Journal of cell biology, 58(2), 419-435.

7. Bidi-Akli S., Arab A., Samraoui B. 2014. Variation spatio-temporelle du zooplancton dans le barrage de la réserve de chasse de Zéralda (Algérie).

8. Bidi-Akli S., Hacene H., Arab A. 2017. Impact of abiotic factors on the spatio-temporal distribution of cyanobacteria in the Zeralda's dam (Algeria).

9. Bouaicha N., Nasri A.B., 2004. First report of cyanobacterium Cylindrospermopsis raciborskii from Algerian freshwaters. Environ Toxicol, 19(5): 541-553.

10. Bouhaddada R.,Nelieu S., Nasri H., Delarue G.,Bouaicha N. 2016. High diversity of microcystins in a Microcystis Bloom from an Algerian lake. Environmental pollution, 216 :836-844

11. Boussadia M.I., Sehli N., Bousbia A., Ouzrout R., Bensouilah M. 2015. The effect of environmental factors on cyanobacteria abundance in Oubeira lake (Northeast Algeria). Research Journal of Fisheries and Hydrobiology, 10(14), 157-168.

12. Bouvy M., Falcão D., Marinho M., Pagano M., Moura A. 2000. Occurrence of Cylindrospermopsis (Cyanobacteria) in 39 Brazilian tropical reservoirs during the 1998 drought. Aquatic microbial ecology, 23(1), 13-27.

13. Bouvy M., Ba N., Ka S., Sane S., Pagano M., Arfi R. 2006. Phytoplankton community structure and species assemblage succession in a shallow tropical lake (Lake Guiers, Senegal). Aquat Microb Ecol 45:147-161

14. Brient L., Vézie C., Bertru G. 2001. Evaluation des efflorescences à cyanobactéries dans des eaux de cours d'eau et plans d'eau breton. Université de Rennes 1, 80 p. [In French]

15. Carey C.C., Ibelings B.W., Hoffmann E.P., Hamilton D.P., Brookes J.D. 2012. Eco-physiological adaptations that favour freshwater cyanobacteria in a changing climate. Water Research, 46: 1394-1407.

16. Carmichael W.W. 1994. The toxins of cyanobacteria. Scientific American, 270 (1), 78-86. 
17. Castenholz R.W., Wilmotte A., Herdman M., Rippka R., Waterbury J.B., Iteman I., Hoffmann L. 2001. Phylum BX. cyanobacteria. In Bergey's Manual ${ }^{\circledR}$ of Systematic Bacteriology (pp. 473599). Springer, New York, NY.

18. Castro D., Vera D., Lagos N., Garcia C., Vasquez M. 2004. The effect of temperature on growth and production of paralytic shellfish poisoning toxins by the cyanobacterium Cylindrospermopsis raciborskii C10. Toxicon, 44: 483-489.

19. Chellappa N.T., Costa M.A.M. 2003. Dominant and co-existing species of Cyanobacteria from a Eutrophicated reservoir of Rio Grande do Norte State, Brazil. Acta Oecologica, 24, S3-S10.

20. Chorus I. 2001. Cyanotoxins, occurence, causes, consequences. Springer-Verlag, Berlin.

21. Cirés S., Ballot A., 2016 A review of the phylogeny, ecology and toxin production of bloomforming Aphanizomenon spp. and related species within the Nostocales (cyanobacteria). Harmful Algae, 54, 21-43.

22. Codd G.A. 2000. Cyanobacterial toxins, the perception of water quality, and the priorisation of eutrophication control. Ecological Engineering 16: 51-60.

23. Dokulil M.T., Teubner K. 2000. Cyanobacterial dominance in lakes. Hydrobiologia, 438(1-3), 1-12.

24. Dokulil M.T., Teubner K. 2011. Eutrophication and climate change : present situation and future scenarios. In: A.A. Ansari, S.S. Gill, G.R. Lanza, W. Rast (Eds), Eutrophication Causes, Consequences and Control: 1-16.

25. Grabowska M., Pawlik-Skowrońska B. 2008. Replacement of Chroococcales and Nostocales by Oscillatoriales caused a significant increase in microcystin concentrations in a dam reservoir. Oceanological and Hydrobiological Studies, 37(4), 23-33.

26. Guellati F.Z., Touati H., Tambosco K., Quiblier C., Humbert J.F., Bensouilah M. 2017. Unusual cohabitation and competition between Planktothrix rubescens and Microcystis sp. (cyanobacteria) in a subtropical reservoir (Hammam Debagh) located in Algeria. PloS one, 12(8), e0183540.

27. Hamilton D.P., Salmaso N., Paerl H.W. 2016. Mitigating harmful cyanobacterial blooms : strategies for control of nitrogen and phosphorus loads. Aquatic Ecology, 50, 351-366.

28. Horvath H., Kovács A.W., Riddick C., Présing M. 2013. Extraction methods for phycocyanin determination in freshwater filamentous cyanobacteria and their application in a shallow lake. European Journal of Phycology, 48:3, 278-286.

29. ISO/TC 147 (International Organisation for Standardization). 1994. Compendum de normes Environnement qualité de l'eau. Tome 2. Méthodes chimiques (ISO/TC 147). 1ére édition.
30. Jia J., Luo W., Lu Y., Giesy J.P. 2014. Bioaccumulation of microcystins (MCs) in four fish species from Lake Taihu, China: assessment of risks to humans. Sci. Total Environ. 487: 224-232.

31. Kokociński M., Stefaniak K., Mankiewicz-Boczek J., Izydorczyk K., Soininen J. 2010. The ecology of the invasive cyanobacterium Cylindrospermopsis raciborskii (Nostocales, Cyanophyta) in two hypereutrophic lakes dominated by Planktothrix agardhii (Oscillatoriales, Cyanophyta). Eur. J. Phycol., 45(4), 365-374.

32. Komárek J., Anagnostidis K. 2005. Cyanoprokaryota: part 2: Oscillatoriales SüBwasserflora von Mittelleuropa freshwater flora of Central Europe. Spektrum Akademischer Verlag Heidelberg. Germany.

33. Kosten S., Huszar V., Becares E., Costa L., Van Donk E., Hansson L.A., Jeppessn E., Kruk C., Lacerot G., Mazzeo N., De Meester L., Moss B., Lurling M., Noges T., Romo S., Scheffer M. 2011. Warmer climate boosts cyanobacterial dominance in shallow lakes. Global Change Biology, 18(1), 118-126.

34. Kuiper-Goodman T., Falconer I., Fitzgerald J. 1999. Human health aspects. In I. Chorus and J. Bartram (Eds.), Toxic Cyanobacteria in Water, A Guide to Their Public Health Consequences, Monitoring and Management (pp.). Published by WHO, Spon Press, London, 125-160.

35. Kurmayer R., Dittmann E., Fastner J., Chorus I. 2002. Diversity of microcystin genes within a population of the toxic cyanobacterium Microcystis spp. in lake Wannsee (Berlin, Germany). Microbial Ecology, 43(1), 107-118.

36. Kurmayer R., Christiansen G., Chorus I. 2003. The abundance of microcystin-producing genotypes correlates positively with colony size in Microcystis $s p$. and determines its microcystin net production in Lake Wannsee. Applied and Environmental Microbiology, 69(2), 787-795.

37. Kurmayer R., Christiansen G., Fastner J., Börner T. 2004. Abundance of active and inactive microcystin genotypes in populations of the toxic cyanobacterium Planktothrix spp.. Environmental Microbiology, 6(8), 831-841.

38. Kurmayer R., Christiansen G. 2009. The genetic basis of toxin production in cyanobacteria. Freshwater reviews, 2(1), 31-50.

39. Leitão M., Couté A. 2005. Guide pratique des cyanobactéries planctoniques du Grand Ouest de la France : Manuel pour les prélèvements et la reconnaissance à l>usage des gestionnaires des eaux de surface: caractéristiques, échantillonnage, identification. Agence de l>eau Seine-Normandie. [In French]

40. Lagos N., Onodera H., Zagatto P. A., Andrinolo D., Azevedo S. M., Oshima Y. 1999. The first evidence of paralytic shellfish toxins in the freshwater 
cyanobacterium Cylindrospermopsis raciborskii, isolated from Brazil. Toxicon, 37(10), 1359-1373.

41. Li R., Carmichael W.W., Brittain S., Eaglesham G.K., Shaw G.R., Mahakhant A., Noparatnaraporn N., Yongmanitchai W., Kaya K., Watanabe M.M. 2001. Isolation and identification of the cyanotoxin cylindrospermopsin and deoxycylindrospermopsin from a Thailand strain of Cylindrospermopsis raciborskii (Cyanobacteria). Toxicon, 39: 973-980.

42. Mehnert G., Leunert F., Cire' S.S., Johnk K., Rucker J., Nixdorf B., Wiedner C. 2010. Competitiveness of invasive and native cyanobacteria from temperate freshwaters under various light and temperature conditions. Journal of Plankton Research, 32: 1009-1021.

43. Messineo V., Melchiorre S., Di Corcia A., Gallo P., Bruno M. 2010. Seasonal succession of $\mathrm{Cyl}$ indrospermopsis raciborskii and Aphanizomenon ovalisporum blooms with cylindrospermopsin occurrence in the volcanic Lake Albano, Central Italy. Environmental Toxicology: An International Journal,25(1), 18-27.

44. Nasri A.B., Bouaïcha N., Fastner J. 2004. First report of a microcystin-containing bloom of the cyanobacteria Microcystis spp. in lake Oubeira, Eastern Algeria. Archives of environmental contamination and toxicology, 46(2), 197-202.

45. Nasri H., Bouchaïcha N., Harche M.K. 2007. A new morphospecies of Microcystis sp forming a bloom in the Cheffia dam (Algeria): seasonal variation of microcystin concentrations in raw water and their removal in a full scale treatment plant. Environmental Toxicology, 22(4), 347-356.

46. Nixdorf B., Mischke U., Rücker J. 2003. Phytoplankton assemblages and steady state in deep and shallow eutrophic lakes - an approach to differentiate the habitat properties of Oscillatoriales. In Phytoplankton and Equilibrium Concept: The Ecology of Steady-State Assemblages (pp. 111121). Springer, Dordrecht

47. Ohtani I., Moore R.E., Runnegar M.T. 1992. Cylindrospermopsin: a potent hepatotoxin from the bluegreen alga Cylindrospermopsis raciborskii. Journal of the American Chemical Society, 114(20), 7941-7942.

48. O’neil J.M., Davis T.W., Burford M.A., Gobler C.J. 2012. The rise of harmful cyanobacteria blooms: the potential roles of eutrophication and climate change. Harmful algae, 14, 313-334.

49. Orr P.T., Rasmussen J.P., M.A Burford., G.K Eaglesham., S.M Lennox. 2010. Evaluation of quantitative real-time PCR to characterize spatial and temporal variations in cyanobacteria, Cylindrospermopsis raciborskii (Woloszynska) Seenaya et Subba Raju and cylindrospermopsin concentrations in three subtropical Australian reservoirs.
Harmful Algae, 9: 243-254.

50. Orr P.T., Jones G.J. 1998. Relationship between microcystin production and cell division rates in nitrogen-limited Microcystis aeruginosa cultures. Limnology and oceanography,43(7), 1604-1614.

51. Paerl H.W., Fulton R. S. 2006. Ecology of harmful cyanobacteria. In Ecology of harmful algae (pp. 95-109). Springer, Berlin, Heidelberg

52. Paerl H.W., Paul V.J. 2012. Climate change: links to global expansion of harmful cyanobacteria. Water research, 46(5), 1349-1363.

53. Pawlik-Skowrońska B., Pirszel J., Kornijów R. 2008. Spatial and temporal variation in microcystin concentrations during perennial bloom of Planktothrix agardhii in a hypertrophic lake, Ann. Limnol. - Int.J.lim.44(2): 63-68

54. Pawlik-Skowrońska B., Toporowska M., Rechulicz J. 2012. Simultaneous accumulation of anatoxin-a and microcystins in three fish species indigenous to lakes affected by cyanobacterial blooms. Oceanological and Hydrobiological Studies, 41(4), 53-65.

55. Poulíčková A., Hašler P., Kitner M. 2004. Annual cycle of Planktothrix agardhii (Gom.) Anagn. \& Kom. nature population. International Review of Hydrobiology: A Journal Covering all Aspects of Limnology and Marine Biology, 89(3), 278-288.

56. Quesada A., E., Moreno D., Carrasco T., Paniagua L., Wormer C., Hoyos De., Sukenik A. 2006. Toxicity of Aphanizomenon ovalisporum (Cyanobacteria) in Spanish water reservoir. European Journal of Phycology, 41: 39-45.

57. Remini B., Achour B., Kechad R. 2010. Les types de foggaras en Algérie. Revue Sciences de l'eau (Canada- France), Vol. 23, n², 105-117.

58. Reynolds C.S. 1996. The plant life of the pelagic. Verh. Int. Ver. Theor. Angew. Limnol. 26, 97-113.

59. Reynolds C.S., Huszar V., Kruk C., Naselli-Flores L., Melo S. 2002. Towards a functional classification of the freshwater phytoplankton. Journal of Plankton Research, 24: 417-428.

60. Rohrlack T., Edvardsen B., Skulberg R., Halstvedt C.B., Utkilen H.C., Ptacnik R., Skulberg O.M. 2008. Oligopeptide chemotypes of the toxic freshwater cyanobacterium Planktothrix can form subpopulations with dissimilar ecological traits. Limnology and Oceanography, 53(4), 1279-1293.

61. Saoudi A., Barour C., Brient L., Ouzrout R., Bensouilah M. 2015. Environmental parameters and spatio-temporal dynamics of cyanobacteria in the reservoir of Mexa (Extreme North-East of Algeria). Advances in Environmental Biology, 9(11), 109-121.

62. Saoudi A., Brient L., Sabrine B., Ouzrout S., Bormans R., Bensouilah M. 2017. Management of toxic cyanobacteria for drinking water production of Ain Zada Dam. Environ Monit Assess, 189:361 
63. Scheffer M., Rinaldi S., Gragnani A., Mur L.R., Van Nes EH. 1997. On the dominance of filamentous cyanobacteria in shallow, turbid lakes. Ecology 78:272-282.

64. Slim K., Fadel A., Atoui A., Lemaire B.J., VinçonLeite B., Tassin B. 2013. Global warming as a driving factor for cyanobacterial blooms in Lake Karaoun, Lebanon. Desalination and Water Treatment, 1-8.

65. Solis M., Pawlik-Skowroñska B., Kalinowska R. 2012. Composition of potentially toxic Cyanobacteria assemblage and microcystin variants in highly eutrophic reservoirs Tomaszne (E. Poland) - Proc. 31th International Conference of Polish Phycological Society, Olsztyn, 18-20.05.2012, Wyd. IRS, Olsztyn: 90.

66. Teneva I., Mladenov R., Dzhambazov B. 2009. Toxic effects of extracts from Pseudanabaena galeata (Cyanoprokaryota) in mice and cell cultures in vitro. Nat. Sci. Hum. 2009, 12, 237-243.

67. Thomas M. K., Litchman E. 2016. Effects of temperature and nitrogen availability on the growth of invasive and native cyanobacteria. Hydrobiologia, 763(1), 357-369.

68. Touati H., Guellati F.Z., Arif S., Bensouilah M. 2019. Cyanobacteria Dynamics in a Mediterranean
Reservoir of the North East of Algeria: Vertical and Seasonal Variability. Journal of Ecological Engineering Vol, 20, 1.

69. Vollenweider R.A., Kerekes J. 1982. Eutrophication of Waters. Monitoring, Assessment and Control. OECD Cooperative Programme on Monitoring of Inland Waters (Eutrophication Control). Environment Directorate, OECD, Paris, 154 pp

70. Welker M., Christiansen G., Van Dohren H. 2004. Diversity of coexisting Planktothrix (Cyanobacteria) chemotypes deduced by mass spectral analysis of microcystins and other oligopeptides. Arch. Microbial. $182: 288-298$.

71. Whitton B. A., Potts M. 2012. Introduction to the cyanobacteria. In Ecology of Cyanobacteria II (pp. 1-13). Springer, Dordrecht.

72. Xie L. Yokoyama A., Nakamura K., Park H. 2007. Accumulation of microcystins in various organs of the freshwater snail Sinotaia histrica and three fishes in a temperate lake, the eutrophic Lake Suwa, Japan - Toxicon 49: 646-652.

73. Yilmaz M., Philips E.J., Szabo N.J., Badylak S. 2008. A comparative study of Florida strains of Cylindrospermopsis and Aphanizomenon for cylindrospermopsin production. Toxicon, 51: 130-139. 